\title{
KARI EKLUND
}

\section{Vaikuttavuudessa ja tuloksellisuudessa iäisyyskysymysten äärellä}

\section{Raimo Etelävuoren laatima}

tarkastuskertomus. Yliopistojen ja

korkeakoulujen aikuiskoulutuksen

arviointia. Valtiontalouden

tarkastusvirasto. DNO 201/54/93.

Syksyllä 1992 yliopistojen täydennyskoulutuskeskukset saivat ylitarkastaja Raimo Etelävuoren allekirjoittaman kirjeen. Kyseessä oli valtiontalouden tarkastusviraston korkeakoulujen täydennyskoulutusta koskeva toiminnantarkastus.

Valtiontalouden tarkastusvirastollahan on jossain määrin pelkoa ja kunnioitustakin herättävä maine. Yleensä viraston puuttuminen asioihin merkitsee ainakin jonkinasteisten väärinkäytös- ten esiintulon mahdollisuutta. Täydennyskoulutuskeskukset eivät olleet silloin — eivätkä vieläkään - vakiinnuttaneet asemaansa. Pelättiin pahinta: valtionvarainmninisteriö yhdessä yliopistojen traditionalistien kanssa poistaa ns. rönsyt ja ainakin yhtiöittää toiminnan ja eriyttää sen ns. yliopiston perustehtävistä. Itsekin lähetteessä työyhteisöni - Jyväskylän yliopiston täydennyskoulutuskeskuksen - muutamalle avainhenkilölle totesin: "Vakavasti otettava paperi! Alkakaapa inventoida aineistoa. Pidetään palaveri."

Sittemmin tilanne laukesi aika tavalla tutustuttuamme Columbo-tyyppiseen tutkinta-aineiston kerääjän henkilökohtaisesti $\mathrm{mm}$. Jyväskylässä. Olimmehan vakuuttuneita täydennyskoulutuksesta yhtenä yliopiston uutena perustehtävänä. Olimme ylpeitä kasvusta ja kehi- 
tyksestä. Näytimme saavamme myös tarkastajan ymmärtämystä ja ainakin paljon odotettua suurempaa mielenkiintoa toimintaamme. Tämä näkyy myös tarkastuskertomuksessa.

Raportin paksuus on 445 sivua. Se jakaantuu yhdeksään päälukuun. Lyhennelmäkin on laajuudeltaan 35 sivua. Lukiessani raportin tammikuun parina viikonloppuna totesin sen jo nykyasussaan vastaavan hyvinkin kasvatustieteiden tai jonkin soveltavan yhteiskuntatieteen lisensiaattityötä aivan tyydyttävällä arvosanalla. Kuitenkin arvosanaa olisi parantanut tekstin lyhentäminen puoleen: sanonnan tiivistäminen ja toistojen vähentäminen sekä johtopäätösten selkeämpi esittäminen. Muutamia havaintoja:

Etelävuorikin joutuu heti alussa toteamaan mm. aikuiskoulutuksen vaikuttavuuden ja tuloksellisuuden arvioinnin vaikeudet. Nämähän ovat olleet myös meille kentän työmyyrille iäisyyskysymyksiä. Olemme olleet lukuisissa arvioinneissa mukana. Kuitenkin yleensä aina joudumme tyytymään enemmän tai vähemmän subjektiivisiin itse- tai vertais- tai ns. asiantuntija-arviointeihin.

Sinänsä Etelävuoren vaatima tarpeellinen tilastopohjan ja talousmittareiden kehittäminenkään ei arvioinnin ongelmaa vielä poista. Toisaalta kovan datan vaatimus voi helposti vääristää koulutuksen suunnittelua ja sisältöä. Ihmisten kehittämisessä ja kehittymisessä useinkaan ei voida päästä luonnontieteelliseen mittaamisen tasoon - eikä ole syytä pyrkiäkään. Niinpä varsinkin kustannukset kattavassa maksullisessa koulutuksessa joudumme tyytymään usein koulutusmarkkinoiden kysynnän antamaan arvioon. Myös tätä kysyntä - vs. tarjontamallin problematiikkaa Etelävuori hyvin pohdiskelee esityksessään.

\section{둘}

Etelävuori kuvaa nykytilannetta ongelmineen varsin osuvasti ja oikein. Uudelle täydennyskoulutuskeskukseen tulevalle työntekijälle raportin voi antaa alaan perehdyttäväksi peruslukemistoksi. Juurikaan virheitä en esityksen faktoissa löydä. Monet toteamukset vanhalle kon- karille ovat kylläkin itsestäänselvyyksiä: täydennyskoulutuskeskusten toiminta on ollut varsin pitkälle virkamiesten henkilöstökoulutusta (mm. opettajat ja sosiaaliala) ja että suhteita ainelaitoksiin on tiivistettävä ja kehitettävä. Sen sijaan laajemmin on pohdittava Etelävuoren suosituksia $\mathrm{mm}$. selvästä valtakunnallisesta aikuiskoulutuksen kehittämisstrategiasta. Samaa Etelävuori haluaa myös yksittäisiltä korkeakouluilta.

Itse vastustan yksiselitteisen selkeitä ylhäältä tulevia linjauksia. Mielestäni asiat eivät ole aikuiskoulutuksenkaan alueella nykymaailmassa selkeitä. Toisaalta yliopistot ovat aina vastustaneet tiukkaa keskusohjausta kaikilla tasoilla. Eiväthän tieteelliset tosiasiatkaan ole muuta kuin eräs muoto väliaikaisuutta.

Väliaikaisuus ei tietysti saa tarkoittaa leväperäisyyttä ja tehottomuutta toiminnassa. Toisaalta ainakin Jyväskylän yliopistossa on hyväksytty ja määritelty (mm. itsearviointien ja kansainvälistenkin arviointien pohjalta) aikuiskoulutuksen vahvuusalueet ja kehittämissuunnat sopivalla joustolla. Myöskin opetusministeriö on täydennyskoulutuskeskuksille suunnatussa varojen jaossaan voinut vetää väljää kehyslinjaa.

Selvä toiminnan linjaus merkitsisi ainakin jossain määrin kysyntämarkkinoista siirtymistä linjan mukaiseen tarjontaohjaukseen. Mielestäni näissä asioissa on löydettävä kohtuullinen balanssi. En siis kannata keskitetyn ohjaamisen lisäämistä. Se ei mielestäni myöskään sovi nykyiseen ainakaan omakatteiseen maksulliseen toimintaan. Asiakkaan tarpeita on syytä paljonkin ottaa huomioon - varsinkin kilpailutilanteessa muiden kouluttajien kanssa (esimerkkinä johtamiskoulutus). Siis useilla lohkoilla toimimme kysyntäsuuntautuneesti ja asiakaslähtöisesti: siltikin oman arviomme mukaan yleensä korkeatasoisen tiedepohjaisesti ja problematisoiden!

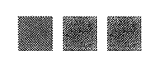

Etelävuoren arviot pitkähköjen täydennyskoulutusohjelmien (PD ja MBA) lisääntymisestä ja virallistumisesta ovat mielenkiintoisia ja rohkaisevia. Julkinen sektori on väljentänyt päte- 
vyysvaatimuksia. Tällöin Etelävuoren arvion mukaan täydennyskoulutuksena tehdyt pitkät ohjelmat alkavat saada merkitystä ammattipätevyyden osoittamisessa.

Vastaavasti peruskoulutuksen merkitys saattaa vähentyä. Samaan suuntaan voi vaikuttaa myös avoimen yliopiston laajeneminen ja ainakin alempien tutkintojen suoritusmahdollisuuksien syntyminen avoimen yliopiston suorituksista. Sivumennen tämähän voi vaikuttaa koko yliopisto-opetukseen. Esimerkiksi 120 opintoviikon taso tehtäisiinkin pääasiassa avoimessa yliopistossa tai muualla. Siten yliopiston resursseja säästyisi ennen kaikkea sen jälkeiseen opiskeluun ja tutkimukseen.

Myös avoimelta yliopistolta Etelävuori vaatii valtakunnan tason toimeenpanosuunnitelmaa. Tässäkin näen lähinnä vain karkean poliittisen tason ohjauksen (esimerkiksi valtioneuvosto) järkeväksi. Yliopistojen ja täydennyskoulutuskeskusten omaa innovatiivisuutta ja yrittämistä tulee kannustaa yksityiskohtaisen ohjauksen sijasta.

Resurssipuolella Etelävuori esittää oikeansuuntaisia näkemyksiä. Opetusvelvollisuuksia tulee nykyistä enemmän voida käyttää myös täydennyskoulutuksessa (ja avoimessa). Samoin virkavapauksia täydennyskoulutuskeskuksen tehtäviin. Muutenkin kiertoa on lisättävä. Uusilla koulutusinnovaatioilla vähennetään myös perusopetuksen resurssien käytön tarvetta.

Hintatuet koko aikuiskoulutusjärjestelmän tasolla vääristävät markkinatilannetta. Samalle lähtöviivalle on pyrittävä. Tätähän valtion uusi maksuperustelaki liiketaloudellisten suoritteiden osalta tarkoittaakin. Riski- ja kehittämisrahaston perustaminen on hyvältä tuntuva ehdotus. Rahoituslähteiden moninaisuus on sinänsä myös vahvuus jne. Lisäksi tilastointia tulee kehittää ja siinä samalla myös teollisuusindikaattoreita. Joidenkin toimintalohkojen yhtiöittämistä on pohdittava. Konkreettinen tutkimustoiminta on kytkettävä aikuiskoulutukseen. Yhteistoimintaa täydennyskoulutuskeskuksien kanssa on lisättävä.
Esitetyt asiat eivät ole aina kovinkaan uusia. Kuitenkin valtiovarainministeriön virkamiehen suusta ne on miellyttävä kuulla.

Kokonaisuudessaan Etelävuori on laatinut hyvän ja perusteellisen nykytilan analyysin korkeakoulujen täydennyskoulutuksesta. Etelävuoren asenne on ollut ennakkoluuloton ja tarvittaessa myös kriittinen ja problematisoiva. Hänen kannanottonsa ovat yleensä melko varovaisia.

Itse täydennyskoulutuskeskuksen sisältä asiaa katsoen olen eri mieltä lähinnä keskusohjauksen lisäämisen korostamisesta. Toisaalta monet omasta henkilökunnastanikin ovat tämänsuuntaisia ajatuksia esittäneet. Kuitenkaan yliopistoja ja niiden yhdeksi perusosaksi kehittyneitä täydennyskoulutuskeskuksiakaan ei voida ohjata yhtenäismallin (selkeä tavoite ja selkeät strategiat) mukaan. Kyse on moniarvoisesta intressien sovittamisesta. Siinä kuitenkin yhteistyö ja tehokas työskentely on mahdollista. Lisäksi täydennyskoulutuksen nykyrahoituksessa kysyntämalli pitää huolen tehottoman ja tarpeettoman koulutuksen häviämisestä. Tosin kysyntämalliakaan en puhtaana halua säilyttää. Tässäkään tilanne ei ole yksiselitteisesti linjattavissa. Tarvitaan kysyntämallin ja tarjontamallin järkevä tasapaino.

Etelävuoren tarkastuskertomus sisältää paljon kommentoitavia yksityiskohtia. Tässä yhteydessä en niihin ole yrittänytkään puuttua. Toivon kuitenkin alan ihmisten tutustuvan julkaisuun ja käyvän keskustelua. 